\title{
Epilepsy and Autism
}

\author{
Ashura W. Buckley ${ }^{1}$ and Gregory L. Holmes ${ }^{2}$ \\ ${ }^{1}$ National Institute Mental Health, Bethesda, Maryland 20892 \\ ${ }^{2}$ Department of Neurological Sciences, University of Vermont College of Medicine, Burlington, Vermont 05405 \\ Correspondence: shu.buckley@nih.gov; gregory.holmes@uvm.edu
}

Epilepsy and autistic spectrum disorder frequently coexist in the same individual. Electroencephalogram (EEG) epileptiform activity is also present at a substantially higher rate in children with autism than normally developing children. As with epilepsy, there are a multitude of genetic and environmental factors that can result in autistic spectrum disorder. There is growing consensus from both animal and clinical studies that autism is a disorder of aberrant connectivity. As measured with functional magnetic resonance imaging (MRI) and EEG, the brain in autistic spectrum disorder may be under- or overconnected or have a mixture of over- and underconnectivity. In the case of comorbid epilepsy and autism, an imbalance of the excitatory/inhibitory (E/I) ratio in selected regions of the brain may drive overconnectivity. Understanding the mechanism by which altered connectivity in individuals with comorbid epilepsy and autistic spectrum disorder results in the behaviors specific to the autistic spectrum disorder remains a challenge.

\begin{abstract}
$A^{\text {utism spectrum disorder (ASD) refers to a }}$ Agroup of complex neurodevelopmental disorders, characterized by deficits in social communication and interaction and demonstrating restricted, repetitive, and stereotyped patterns of behavior. The symptoms are present from early childhood and are impairing to everyday functioning. People with ASD have co-occurring intellectual disability (ID), language disorder, and epilepsy at higher rates than the general population. The exact prevalence of ASD is difficult to ascertain, but the rate of diagnosis is rising and best estimates put the prevalence between 1 in 88 and 1 in 100 individuals (Buescher et al. 2014). Estimates from the Centers for Disease Control and Prevention (CDC) (Baio et al. 2014) predict that, soon, 1 in 68 will be diagnosed with ASD.
\end{abstract}

The rate of increase in diagnosis, coupled with the limited effectiveness of treatments and the costs of care for these patients makes autism a growing public health concern.

There is substantial evidence that genetics plays an important role in ASD (Risch et al. 1999; Anney et al. 2010; Gaugler et al. 2014; Pinto et al. 2014). However, delineating the exact contribution of genes to the eventual behavioral expression of ASD in any given individual is complicated. For example, we currently recognize $>50$ genes or genomic variants, as well as numerous copy number variations (CNVs), that either cause or predispose individuals to ASD (Zoghbi 2003; Abrahams and Geschwind 2008; Geschwind 2008; Sudhof 2008; Sanders et al. 2011). In addition to the number of poten-

Editors: Gregory L. Holmes and Jeffrey L. Noebels

Additional Perspectives on Epilepsy: The Biology of a Spectrum Disorder available at www.perspectivesinmedicine.org

Copyright (C) 2016 Cold Spring Harbor Laboratory Press; all rights reserved; doi: 10.1101/cshperspect.a022749

Cite this article as Cold Spring Harb Perspect Med 2016;6:a022749 
A.W. Buckley and G.L. Holmes

tial causative genes, the known ASD-related proteins (including those mapping within CNVs) span diverse categories, from transcription factors (Amir et al. 1999; Voineagu et al. 2011) to RNA-binding proteins (Bassell and Warren 2008) and cell-adhesion molecules (Wang et al. 2009), to enzymes involved in protein modification (Geschwind 2008; Walsh et al. 2008) and degradation (Beaudet 2007). Further complicating efforts to trace the pathogenesis of the disorder, it is also known that environmental factors may play an important role in the development of ASD (Hallmayer et al. 2011).

Since the earliest writings about ASD, there has been a known association with epilepsy (Kanner 1968) and a tacit recognition that both conditions often exist in the same individual at a much higher rate than would be expected by chance alone (Tuchman and Rapin 2002; Matsuo et al. 2010; Tuchman and Cuccaro 2011; Tuchman et al. 2013). This association between epilepsy and ASD has challenged researchers to find the pathophysiological link between the two conditions. Because of the myriad of genetic and nongenetic causes resulting in both epilepsy and ASD, a singular pathophysiological mechanism responsible for the seizures and autistic phenotype is unlikely. However, the high rate of co-occurrence of epilepsy and ASD has led many to search for common pathological links between the two conditions that could provide a final pathway to either seizures or ASD. Precisely because any number of deviations from normal development could potentially alter brain function, there is great utility in trying to identify the shared "end products" of such alterations that result in seizures, ASD, or both. In this article, we explore common threads that may account for this high comorbidity rate.

\section{PREVALENCE OF COMORBID AUTISM AND EPILEPSY}

Estimates of the prevalence of epilepsy in ASD vary widely, with some studies reporting almost 50\% (Spence and Schneider 2009). The variation in prevalence appears to directly relate to the differences in sample characteristics between studies, such as cohort size, ascertain- ment factors, age, inclusion or exclusion of patients with conditions known to have a high rate of epilepsy, such as tuberous sclerosis complex (TSC), and the presence or absence of ID (Spence and Schneider 2009). Clinic-based samples report the highest rates, as patients with epilepsy are often overrepresented in these settings (Hughes and Melyn 2005). Populationbased studies avoid this bias and provide the best estimate of true prevalence of epilepsy in autism, but even in these reports, rates have been variable (Danielsson et al. 2005; Saemundsen et al. 2013). In a meta-analysis of studies conducted from 1963 to 2006, the pooled prevalence of epilepsy was $21.5 \%$ in individuals with ASD with ID compared with $8 \%$ in ASD without ID (Amiet et al. 2008). In a more recent meta-analysis of 16 studies, the rate of epilepsy was $8.9 \%$ in individuals without an ID but $23.7 \%$ in those with an ID (Woolfenden et al. 2012). In addition to ID, the age of the participants influences the prevalence rates. In a large cross-sectional study evaluating 5815 people with ASD, the average prevalence of epilepsy differed by age of the cohort examined, with a prevalence rate of $12.5 \%$ in children between 2 and $17 \mathrm{yr}$ but $26 \%$ in those $13 \mathrm{yr}$ or older (Viscidi et al. 2013). In children with ASD, having co-occurring epilepsy has been associated with a higher rate of cognitive deficits, and frontal lobe epileptiform activity (Matsuo et al. 2011) when compared with children with ASD alone. Although there is a strong association between co-occurring ID and ASD in populations of people with epilepsy (Viscidi et al. 2013), studies have indicated that even in cases with a normal IQ there is evidence that autism itself is associated with an increased risk of epilepsy (Olsson et al. 1988; Elia et al. 1995; Amiet et al. 2008).

Not only does having ASD increase the risk of developing epilepsy, but the prevalence of ASD in individuals with epilepsy is substantially higher than the prevalence of ASD in the general population (Tuchman and Cuccaro 2011; Woolfenden et al. 2012). In a large population-based cohort of 64,188 people with epilepsy, the odds ratio of having ASD was 22.2 (95\% CI; 16.8-29.3) (Selassie et al. 2014). Two large prospective studies have looked at 
rates of ASD within an epilepsy population and found that $\sim 4 \%-5 \%$ of children with epilepsy had ASD (Berg et al. 2011; Geerts et al. 2011). In studies of children with epilepsy in an English school system, $\sim 21 \%$ had ASD (Reilly et al. 2014, 2015). The developmental sequelae of seizures early in life includes a particularly high risk for developing autism (Saemundsen et al. 2007, 2008, 2013).

\section{PREVALENCE OF EEG ABNORMALITIES IN AUTISM}

In addition to an increased prevalence of epilepsy in individuals with ASD, there is also a marked increased incidence of epileptiform activity on the EEGs of people with ASD (Giovanardi et al. 2000; Hrdlicka et al. 2004; Canitano et al. 2005; Gabis et al. 2005; Hughes and Melyn 2005; Baird et al. 2006; Chez et al. 2006; Kim et al. 2006; Akshoomoff et al. 2007; Hara 2007; Parmeggiani et al. 2007; Giannotti et al. 2008; Spence and Schneider 2009). Whereas interictal spikes occur in $>5 \%$ of normally developing children without a history of epilepsy (EegOlofsson et al. 1971), more recent studies have shown that up to $60 \%$ of EEG records from children with ASD have interictal spikes (Hughes and Melyn 2005) and many of the children with abnormal EEGs do not have a history of epilepsy (Hughes et al. 2015). The location of spikes in children with ASD also differs from their typical peers with a higher percentage of interictal spikes in the frontal lobe in children with ASD than in those without ASD (Fig. 1) (Hashimoto et al. 2001; Matsuo et al. 2010).

\section{GENETICS OF EPILEPSY AND AUTISM}

Although there is a high comorbidity rate between ASD and epilepsy and between ASD and EEG epileptiform activity, this relationship is not necessarily a causal one. It is far more likely that epilepsy and ASD have a complex interaction and possibly share common pathophysiological properties.

One way to approach these shared interactions is to study genetic syndromes in which epilepsy and ASD frequently coexist (Table 1).

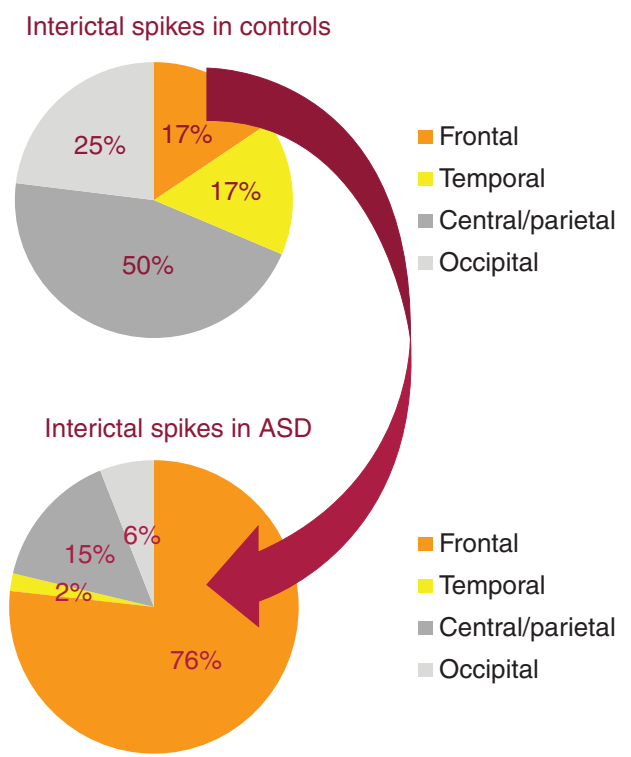

Figure 1. Interictal spikes in normal children without seizures and children with ASD. Note that frontal lobe spikes are more common in children with ASD than controls (based on data in Hashimoto et al. 2001 and Eeg-Olofsson et al. 1971, respectively).

In these syndromes, there is a disproportionately increased risk of developing both/either ASD and epilepsy compared with the general population. A large proportion of the genes associated with ASD in humans or with autisticlike behaviors (ALBs) in mice, are also associated with epilepsy.

TSC offers a natural paradigm through which we can begin to understand the relationship between epilepsy and ASD in neurodevelopmental disorders. TSC is an autosomal dominant inherited disorder of high penetrance, characterized pathologically by the presence of hamartomas (tumor-like lesions) in multiple organ systems (Holmes and Stafstrom 2007). Many patients also have renal lesions; usually angiomyolipomas and cysts, polycystic renal disease, and renal carcinoma can also occur. The neurological manifestations of TSC are particularly challenging and include infantile spasms, intractable epilepsy, cognitive disabilities that vary from mild learning disabilities to severe intellectual impairment, ASD, and behavioral disturbances. 
A.W. Buckley and G.L. Holmes

Table 1. Genetic syndromes with ASD and epilepsy coexisting

\begin{tabular}{|c|c|c|c|}
\hline Syndrome & Percent with ASD & Percent with seizures & Co-occurrence \\
\hline $\begin{array}{l}\text { Angelman } \\
\text { syndrome }\end{array}$ & $\begin{array}{l}\text { 1.9\% (Veltman et al. } \\
\text { 2005) } \\
42 \% \text { (Peters et al. 2004) }\end{array}$ & $\begin{array}{l}85 \% \text { (Fiumara et al. 2010) } \\
100 \% \text { (Valente et al. 2006) }\end{array}$ & $\begin{array}{l}\text { Case study }(n=4) \text { with ASD } \\
\text { reports all had seizure } \\
\text { disorders (Steffenburg et al. } \\
\text { 1996) }\end{array}$ \\
\hline $\begin{array}{l}\text { Cornelia de Lange } \\
\text { syndrome }\end{array}$ & $\begin{array}{l}\text { 32\% (Oliver et al. 2008) } \\
39 \% \text { (Moss et al. 2008) } \\
65 \% \text { (Moss et al. 2012) }\end{array}$ & $\begin{array}{l}23 \%-26 \% \text { (Pavlidis et al. } \\
\text { 2014) }\end{array}$ & \\
\hline Down syndrome & $\begin{array}{l}\text { 3.1\% (Kohane et al. } \\
\text { 2012) } \\
5.8 \% \text { (Lowenthal et al. } \\
\text { 2007) } \\
\text { 18.2\% (DiGuiseppi et al. } \\
\text { 2010) }\end{array}$ & $\begin{array}{l}\text { 1\%-13\% (Verrotti et al. } \\
2013 \text { ) } \\
8 \% \text { (Goldberg-Stern et al. } \\
2001)\end{array}$ & $\begin{array}{l}\text { Seizures occur significantly } \\
\text { more often in ASD + Down } \\
\text { than in Down only control } \\
\text { (Molloy et al. 2009) }\end{array}$ \\
\hline Dravet syndrome & $\begin{array}{l}\text { 24.3\% ( Li et al. 2011) } \\
\text { 61.5\% (Berkvens et al. } \\
\text { 2015) }\end{array}$ & $\begin{array}{l}100 \% \text { (Wolff et al. 2006) } \\
100 \% \text { (Berkvens et al. 2015) }\end{array}$ & \\
\hline $\begin{array}{l}\text { Duchenne } \\
\text { muscular } \\
\text { dystrophy }\end{array}$ & $\begin{array}{l}\text { 15\% (Banihani et al. } \\
\text { 2015) }\end{array}$ & $6.3 \%$ (Pane et al. 2013) & \\
\hline Fragile X syndrome & $\begin{array}{l}\text { 21\% (Kohane et al. 2012) } \\
30 \% \text { (Miles 2011) }\end{array}$ & $\begin{array}{l}11.8 \%-18 \% \text { (Berry-Kravis } \\
2002 \text { ) }\end{array}$ & $\begin{array}{l}\text { Case study }(n=57) \text { with ASD } \\
\text { found } 28.1 \% \text { had seizures } \\
\text { (Garcia-Nonell et al. } 2008)\end{array}$ \\
\hline $\begin{array}{l}\text { Hypomelanosis of } \\
\text { Ito syndrome }\end{array}$ & $\begin{array}{l}\text { 10\% of patients with ID } \\
\quad \text { (Pascual-Castroviejo } \\
\text { et al. 1998) } \\
64 \% \text { (Zappella 1993) }\end{array}$ & $\begin{array}{l}11.5 \%-50 \% \text { (Ruggieri and } \\
\text { Pavone } 2000) \\
37 \%-53 \% \text { (Assogba et al. } \\
\text { 2010) } \\
49 \% \text { (Pascual-Castroviejo } \\
\text { et al. } 1998 \text { ) }\end{array}$ & $\begin{array}{l}\text { Most children with ID and } \\
\text { autism had infantile spasms } \\
\text { or severe drug-resistant } \\
\text { seizures (Ruggieri and Pavone } \\
\text { 2000) }\end{array}$ \\
\hline $\begin{array}{l}\text { Mowat-Wilson } \\
\text { syndrome }\end{array}$ & 40\% (Evans et al. 2012) & $\begin{array}{l}\text { 70\%-75\% (Cordelli et al. } \\
2013 \text { ) }\end{array}$ & \\
\hline Rett syndrome & $\begin{array}{l}\text { Transient autism features } \\
\text { (Chahrour 2007; Percy } \\
\text { 2011) }\end{array}$ & $61 \%($ Bao 2013) & \\
\hline $\begin{array}{l}\text { Phelan- } \\
\text { McDermid } \\
\text { syndrome }\end{array}$ & $\begin{array}{l}\text { 0\%-94\% (Kolevzon } \\
\quad 2014) \\
26 \%(\text { Sarasua et al. 2014) } \\
31 \% \text { (Sarasua et al. 2014) }\end{array}$ & $\begin{array}{l}0 \%-40 \%(\text { Kolevzon } 2014) \\
27 \%(\text { Sarasua et al. } 2014)\end{array}$ & \\
\hline $\begin{array}{l}\text { Pitt-Hopkins } \\
\text { syndrome }\end{array}$ & $100 \%$ (Sweatt 2013) & $50 \%$ (Sweatt 2013) & \\
\hline $\begin{array}{l}\text { Prader-Willi } \\
\text { syndome }\end{array}$ & $\begin{array}{l}25.3 \% \text { (Veltman et al. } \\
\text { 2005) }\end{array}$ & $\begin{array}{l}\text { 13.5\% (Gilboa } 2013) \\
26 \%(\text { Vendrame } 2010)\end{array}$ & \\
\hline Sotos syndrome & $\begin{array}{l}\text { Rare (Mouridsen 2002; } \\
\quad \text { Buxbaum 2007) }\end{array}$ & $41 \%$ (Tatton-Brown 2004) & \\
\hline $\begin{array}{l}\text { Smith-Lemli- } \\
\text { Opitz syndrome }\end{array}$ & 53\% (Tierney 2001) & $\begin{array}{l}\text { Epileptiform discharges are } \\
\text { common but low } \\
\text { prevalence of epilepsy } \\
\text { (Schreiber 2014) }\end{array}$ & $\begin{array}{l}\text { Autism symptoms more } \\
\text { prevalent in group with } \\
\text { interictal epileptiform } \\
\text { discharges (Schreiber 2014) }\end{array}$ \\
\hline $\begin{array}{l}\text { Smith-Magenis } \\
\text { syndrome }\end{array}$ & 90\% (Laje 2010) & $45 \%$ (Goldman 2005) & \\
\hline
\end{tabular}


Epilepsy and Autism

Table 1. Continued

\begin{tabular}{lccc}
\hline Syndrome & Percent with ASD & Percent with seizures & Co-occurrence \\
\hline Tuberous sclerosis & $10.8 \%$ (Kohane et al. & $70 \%-80 \%$ (Crino 2006) & $75 \%-100 \%$ of patients with \\
complex & 2012 ) & & ASD will also have seizures \\
& $25 \%-50 \%$ (Wiznitzer & & (Wiznitzer 2004) \\
& $2004)$ & \\
\hline
\end{tabular}

ASD, Autism spectrum disorder; ID, intellectual disability.

The majority of individuals with TSCs have mutations of Tsc1 (encoding for the protein hamartin) or Tsc2 (encoding for the protein tuberin). Hamartin and tuberin proteins form a functional complex, which inhibits the serine/ threonine protein kinase mammalian target of rapamycin (mTOR) (Curatolo et al. 2015). The mTOR kinase complex is the central component of a cell-growth pathway that responds to changes in nutrients, energy balance, and extracellular signals to control cellular processes including protein synthesis, energy metabolism, and autophagy (Laplante and Sabatini 2012). Loss-of-function of the $T s c 1$ and $T s c 2$ protein complex results in deregulated and constitutively active mTOR complex 1 , which promotes cell growth and contributes to tumor formation in dividing cells including the hamartomas and giant cells that are characteristic of TSC.

In TSC, early seizure onset is associated with a high risk for ASD (Numis et al. 2011; van Eeghen et al. 2013). In a retrospective review of 103 patients with TSC, 40\% were diagnosed with an ASD (Numis et al. 2011). Patients with ASD also had an earlier age-at-seizure onset, more frequent seizures, and their EEG recordings had a significantly greater amount of interictal epileptiform features in the left temporal lobe when compared with those patients who did not develop ASD. These investigators concluded that ASD may be associated with persistent seizure activity early in development, particularly when it occurs in brain regions integral to the proper development of social perception and communication. Supporting this hypothesis is the fact that the risk of ASD in TSC can be reduced by early treatment of the epilepsy. In a long-term study of children with TSC identified as infants and followed for $3.5 \mathrm{yr}$, the difference in the proportion of who developed a co-occur- ring epilepsy between children treated early with vigabatrin (9\%) and children treated later (52\%) was quite stark (Cusmai et al. 2011). Thus, early treatment of seizures in TSC seems to clearly reduce but not eliminate the risk of ASD in this disorder (Bombardieri et al. 2010; Cusmai et al. 2011).

Although these studies implicate seizures in the development of ASD in children with TSC, especially when they are medically intractable and occur early in the course of neurodevelopment, these findings still do not prove causation. The children with more severe TSC who will eventually develop ASD may be a distinct group from those children with TSC who remain socially and intellectually intact. It is entirely possible that whatever sets this group apart is also responsible for the "nonresponse" to antiepileptic intervention, and that the link between autism and epilepsy lies within a common pathophysiologic substrate responsible for the child's vulnerability to both conditions.

Mouse models of TSC show behavioral changes paralleling human disease phenotypes, including seizures, deficits in learning and memory, and ALB (Ehninger et al. 2008; Meikle et al. 2008; Young et al. 2010; Tsai et al. 2012).

Functional mutations in $T s c 1$ or $T s c 2$ significantly alter synapse structure, function, and plasticity (Tavazoie et al. 2005; Ehninger et al. 2008; Auerbach et al. 2011; Bateup et al. 2011; Chevere-Torres et al. 2012). Protein synthesis, regulated by TSC-mTOR signaling, plays a role in learning-associated synaptic changes. In TSC, increased local availability of proteins may stabilize plasticity at synapses that would not normally undergo synaptic consolidation. The net result is to increase the signal-to-noise ratio and degrade the specificity of synaptic modifications that occur during normal learning, as evidenced 
A.W. Buckley and G.L. Holmes

by lower thresholds for the induction of latephase long-term potentiation (LTP) in mouse models of TSC (Banko et al. 2005; Costa-Mattioli et al. 2005; Ehninger et al. 2008). Rapamycin, an mTOR inhibitor, not only reverses abnormal synaptic consolidation but also restores learning deficits in $\mathrm{Tsc}^{+}$mice (Ehninger et al. 2008).

Although it is clear that perturbations of Tsc1/2 and mTOR alter many aspects of neuronal function, it is unclear which alterations are directly causal and which are induced secondarily as a consequence of altered brain function. To address this issue, Bateup et al. (2011) knocked out $T s c 1$ selectively in CA1 pyramidal neurons in P14-16 mouse pups. The loss of Tscl produced hyperexcitable pyramidal cells caused by deficits in inhibitory synaptic function manifested as decreased amplitude of miniature inhibitory currents, reduced evoked inhibitory currents, and reduced synaptic inhibitory potentials. These studies suggest that Tscl is critical for establishing inhibitory synapses onto CA1 pyramidal cells. The overall deficit in inhibitory drive onto pyramidal cells resulted in a disrupted E/I ratio and increased hippocampal network activity both in vivo and in vitro. The observed reduction in inhibition was reversed by blocking mTOR activity with rapamycin, suggesting that amelioration of the signaling abnormality can restore normal cell activity. Thus, disrupted development of inhibitory synaptic transmission is likely an important consequence of altering Tscl/2-mTOR signaling and restoration of E/I balance may stabilize normal cell activity. Indeed, artificial elevation of cellular E/I ratio has also been shown to disrupt information processing and social behavior in mice, further suggesting that stabilization of the balance between excitatory and inhibitory drive is important for cognitive function (Yizhar et al. 2011). Maintenance of $\mathrm{E} / \mathrm{I}$ balance has also been shown to drive normal hippocampal oscillations. In oscillating hippocampal pyramidal cells synaptic excitation is immediately followed by a proportional synaptic inhibition, and modification of the amplitude of these events directly modulates oscillation frequency (Atallah and Scanziani 2009).
Another example of a genetic syndrome with a high incidence of both ASD and epilepsy is fragile X syndrome (FXS). FXS is the most common inherited form of ID in males, occurring in $\sim 1$ in 4000 males (Turner et al. 1996). Many of the children have both autism and epilepsy (Wheeler et al. 2015). Mutations in the FMR1 gene in FXS result in reduced production of the fragile X mental retardation 1 protein (FMRP). This protein helps regulate the production of other proteins and plays a role in the development of synapses. Nearly all cases of FXS are caused by a mutation, in which the CGG triplet repeat is expanded within the FMR1 gene. Normally, this DNA segment is repeated from 5 to $\sim 40$ times. However, in individuals with FXS, the CGG segment is repeated >200 times. The abnormally expanded CGG segment turns off (silences) the FMR1 gene, which prevents the gene from producing FMRP. Loss or deficiency of this protein disrupts nervous system functions and leads to the signs and symptoms of FXS.

FMRP knockout mice show ALB (Mines et al. 2010; Paz et al. 2013; Tyzio et al. 2014). The knockouts have a significant increase in global protein synthesis and in protein synthesis at the synapse (Bassell and Warren 2008). These knockouts have impaired synaptic plasticity, alterations in dendritic morphology, and neurocognitive deficits in FMRP mutants, indicating a major role for FMRP in the regulation and maintenance of synaptic function. It has been suggested that exaggerated signaling through mGluR5 can account for multiple cognitive and syndromic features of FXS (Dolen and Bear 2008). As with TSC, imbalances in $\mathrm{E} / \mathrm{I}$ may contribute to both the impaired behavior and to seizures in the mouse model.

Other genetic models of epilepsy and autism have also suggested that an imbalance of the $\mathrm{E} / \mathrm{I}$ ratio contributes to both the development of ALB and to seizures. SynGAP1, a synaptic Ras GTPase-activating protein is involved in NMDA receptor synaptic plasticity and in membrane insertion of the $\alpha$-amino-3-hydroxy-5-methyl-4-isoxazolepropionic acid (AMPA) receptor. Syngap1 haploinsufficiency in mice can cause cognitive impairment, seizures, and ALB. Haploinsufficiency restricted to just forebrain gluta- 
matergic neurons is sufficient to disrupt cognition. Restoring mutations from this population prevents cognitive abnormalities; whereas, manipulating Syngap 1 function in $\gamma$-aminobutyric acid (GABA)ergic neurons had no effect on cognition, excitability, or neurotransmission, indicating the specificity of Syngap1 mutations within forebrain excitatory neurons. In this model, cognitive abnormalities were induced by Syngap1 dysfunction in developing but not in mature forebrain neurons. It is likely that the isolated impairment of forebrain glutamatergic neurons in Syngap1 mutants disrupts synaptic homeostasis and alters the balance of E/I at a critical window in development (Clement et al. 2012; Ozkan et al. 2014).

Homologous mutations of CNTNAP2, which encode contactin-associated protein-like 2 , result in cortical dysplasia, focal epilepsy, and macrocephaly (Strauss et al. 2006). People with this mutation develop intractable focal seizures beginning in early childhood, after which language regression occurs and is often accompanied by hyperactivity, impulsive and aggressive behavior, cognitive impairment, and ASD (Strauss et al. 2006). In common with some patients with CNTNAP2 mutations, CNTNAP2 mutant mice have epileptic seizures and ALB. In this mouse model, migration of cortical projection neurons is impaired, as is cortical neuronal synchrony, and the number of GABAergic interneurons (Penagarikano et al. 2011). Taken together, these changes likely indicate abnormalities in $\mathrm{E} / \mathrm{I}$.

Mice with PRICKLE1 mutations show both ALB and seizures. Endogenous Prickle1 and synapsin 1, a protein involved in synaptogenesis, synaptic vesicle formation and regulation of neurotransmitter release, colocalize in neurons and physically interact. Mutations in PRICKLE1 disrupt its ability to increase the size of synaptic vesicles. Studies suggest that PRICKLE1 mutations contribute to ALB and seizures by disrupting the interaction with synapsin 1 and the regulation of synaptic vesicles, thus leading to abnormalities in the E/I ratio (Paemka et al. 2013, 2015).

Although genetic mouse models of epilepsy and ALB suggest that E/I balance has a role in both the epilepsy and the aberrant behavior, it should be cautioned that the development of ALB and seizures is likely far more complex. As in the clinical situation in which most children with ASD do not have epilepsy, there are a significant number of mouse models of autism, which do not have seizures. Although a common pathway may link epilepsy and ALB in some of the genetic models, extrapolation of altered $\mathrm{E} / \mathrm{I}$ to all autism models is not possible.

\section{ALTERED E/I BALANCE AND CONNECTIVITY}

The idea that altered E/I balance can play a role in ALB in rodents has been supported by studies of early-life seizures (ELS) (Holmes et al. 2015). In this model of acquired ASD, rats received 70 seizures over $10 \mathrm{~d}$ spanning postnatal $(\mathrm{P}) \mathrm{d} 5$ 14. Seizures were induced by the convulsant inhalant, flurothyl. Previous work with this model showed that rats with ELS have persistent increased excitation (Isaeva et al. 2010) and decreased GABA currents (Isaeva et al. 2009) in the neocortex and a substantially reduced lower seizure threshold (Holmes et al. 2015). ELS also have been shown to increase short-term plasticity in the mesial prefrontal cortex (mPFC) (Hernan et al. 2013). Alterations in short-term plasticity in the mPFC have been associated with changes in hippocampal-PFC synchrony (Sigurdsson et al. 2010; Fenelon et al. 2013). Taken together, these findings suggest there is a long-standing increase in the $\mathrm{E} / \mathrm{I}$ ratio in the mPFC. Similar to children with ASD, rats with ELS have impaired sociability (Lugo et al. 2014) and behavioral inflexibility (Kleen et al. 2011a).

To understand how altered E/I balance results in autistic-like behavior, multisite local field potentials (LFP) within and between brain regions that are critical for cognition, the medial prefrontal cortex (mPFC), ventral (VH), and dorsal hippocampus $(\mathrm{DH})$ in the ELS model were assessed following ELS (Holmes et al. 2015). Because ASD presents in early childhood and brain connectivity changes with age (DoyleThomas et al. 2015), the studies were performed serially in developing rats from $\mathrm{P} 18-\mathrm{P} 25$. These ages would be human equivalent age of 5 to $6 \mathrm{yr}$ 
A.W. Buckley and G.L. Holmes

(Clancy et al. 2007; Workman et al. 2013). Coherence was used as a measure of functional connectivity between brain regions during cognitive tasks. Coherence is a measure of "coupling" oscillations and, therefore, provides a functional link between brain areas required for the integration of distributed information (Varela et al. 2001; Thatcher 2012). Coherences are dynamic and, as we have shown previously in the ELS model (Kleen et al. 2011b), are related to short-term memory. Pearson product corre-

A

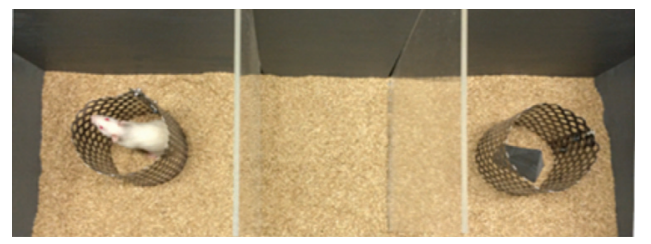

C

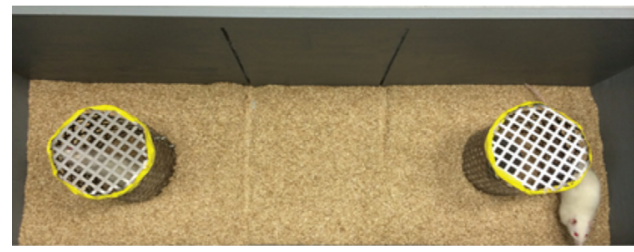

E

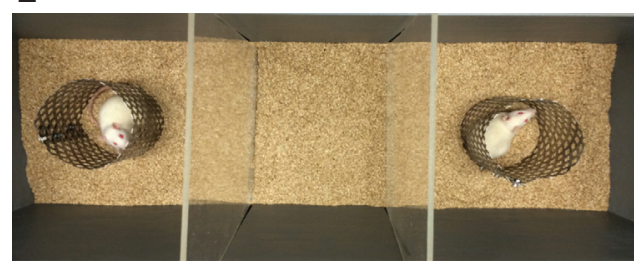

In rat pups with ELS, field recordings from $\mathrm{DH}, \mathrm{VH}$, and $\mathrm{mPFC}$ show marked increases in coherence as well as decreases in voltage correlation at all bandwidths compared with controls, although there were minimal differences in total power and relative power spectral densities. The alterations in coherences and voltage correlation occurred within days (P18) of the last seizure and suggested that the brains of ELS are overly connected and weakly modulated by distant brain rhythms.

Rats with ELS had resulting impairment in the sociability and social novelty tests (Fig. 2) and behavioral flexibility but showed no evidence of increased motor activity or generalized anxiety as measured in the open field. For example, rats with ELS showed no differences in coherence measurements when the rat approached an object or another rat. Although

\section{B}

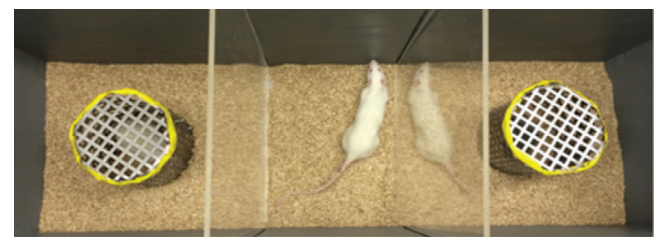

D

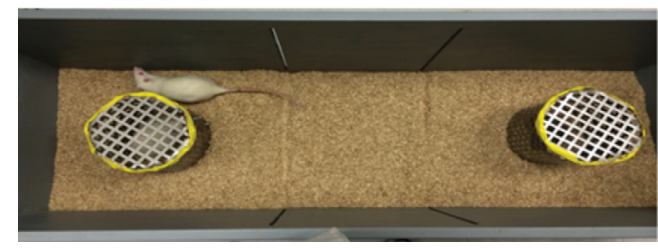

$\mathbf{F}$

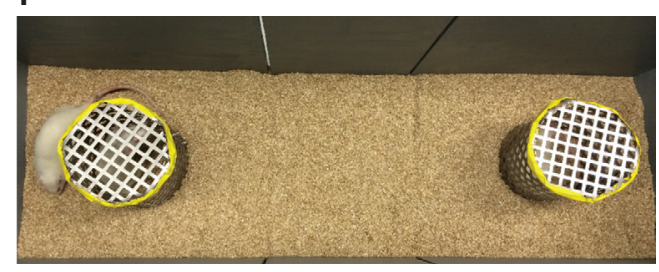

Figure 2. Sociability and social novelty test. (A) Rectangular wood box with opaque sides divided into three equal squares using removable plastic doors. An unfamiliar male rat is placed in one grated cylinder and an object in the other. $(B)$ Starting point for test with test rat placed in the center square for $5 \mathrm{~min}$. The rat and object cylinders are covered. $(C)$ Once doors are removed, the animal is allowed to wander in the chamber for $10 \mathrm{~min}$ (sociability test). In $C$, the rat is spending time near the object. $(D)$ Rat spending time near the other rat. (E) After $15 \mathrm{~min}$, a new rat replaces the object. $(F)$ The test rat was then tracked for time investigating the new and old rat (social novelty test). 
in contrast, control rats' coherences were higher when presented with another rat than with an object, suggesting limited plasticity in connectivity during this social task in those animals with ELS. This study showed that ELS in otherwise normal rodents can result in acquired deficits in social behaviors. These data suggested that one possible pathway by which ELS can result in an autistic-like phenotype is through alterations in the dynamic flexibility of brain connectivity, manifesting as enhanced coherences across a broad span of frequencies (Fig. 3).

To determine whether preventing the increased E/I ratio following ELS could prevent the alterations in coherence and behavior, bumetanide, a pharmacological agent that blocks the activity of NKCC1 and induces a significant shift of $\mathrm{E}_{\mathrm{Cl}}$ toward more hyperpolarized values, was administered at the time of the ELS seizures (Holmes et al. 2015). Treatment with bumetanide at the time of the seizures totally prevented the subsequent increases in coherence and resulted in normal sociability. Similarly, Tyzio et al. (2014) reported that bumetanide restored the impaired oxytocin-mediated GABA excitatory-inhibitory shift during delivery in the valproate and fragile $\mathrm{X}$ rodent models of autism, ameliorating ALB characteristics in the offspring.

\section{Aberrant Connectivity in Autism}

Similar to the rodent studies, there is increasing evidence from both imaging and neurophysiologic studies pointing to altered brain connectivity as a key feature of the pathophysiology of ASD (Casanova and Trippe 2009; Dinstein et al. 2011; Kana et al. 2011; Muller et al. 2011). Additionally, there is some evidence that the changes in neuronal organization in ASD are differentially expressed with age, marked by early life brain overgrowth including increased neuron number, followed by decreases in both structural volumes and neuron number as the brain ages. Courchesne $(2002,2004)$ and Courchesne and colleagues (2003) identified growth abnormalities in frontal, cerebellar, and temporal structures that normally mediate the development of higher order social, emotional, speech, language, attention, and cognitive functions that are often abnormal in ASD. In other structures (e.g., occipital cortex), known to mediate functions that are either mildly or entirely unaffected in ASD patients, growth pathologies are milder or nonexistent (Courchesne et al. 2005).

In parallel with these changes in volume in both gray and white matter (Lange et al. 2015), imaging techniques have shown changes in brain connectivity as well (Chen et al. 2011; Pina-Camacho et al. 2012). Magnetic resonance imaging (MRI) studies have consistently shown differences in individuals with autism compared with normal controls. Reports have been published revealing reduced long-range, distant brain connectivity during both task-specific (Besag 2004; Koshino et al. 2005, 2008; Kana et al. 2006; Just et al. 2007) and restingstate paradigms (Cherkassky et al. 2006; Weng et al. 2010). Likewise, a number of studies have shown reduced short-range, local connectivity (Besag 2004; Koshino et al. 2005, 2008; Just et al. 2007; Kana et al. 2011). Results from yet other studies have shown increased connectivity, both long range (Ben Bashat et al. 2007; Cheng et al. 2010; Supekar et al. 2013) and short range (Weng et al. 2010; Anderson et al. 2011; Keown et al. 2013; Khan et al. 2013; Lewis et al. 2013).

Connectivity differences in ASD have also been evaluated by EEG. As in the imaging reports, the resulting evidence is conflicting and inconsistent. Twenty-one studies in the last decade have been published; 11 evaluated resting state (Murias et al. 2007; Coben et al. 2008; Barttfeld et al. 2011; Bosl et al. 2011; Duffy and Als 2012; Mathewson et al. 2012; Sheikhani et al. 2012; Leveille and Hannagan 2013; Peters et al. 2013; Machado et al. 2015), eight were task related (Isler et al. 2010; Lazarev et al. 2010; Catarino et al. 2013; Garcia Dominguez et al. 2013; Carson et al. 2014; Orekhova et al. 2014; Righi et al. 2014; Lazarev et al. 2015; Machado et al. 2015); one obtained during non-rapid eye movement (NREM) sleep (Lazar et al. 2010) and one obtained during rapid eye movement (REM) sleep (Leveille et al. 2010). It is not possible to directly compare these studies as the acquisition paradigm, the age of the subjects, 
A.W. Buckley and G.L. Holmes
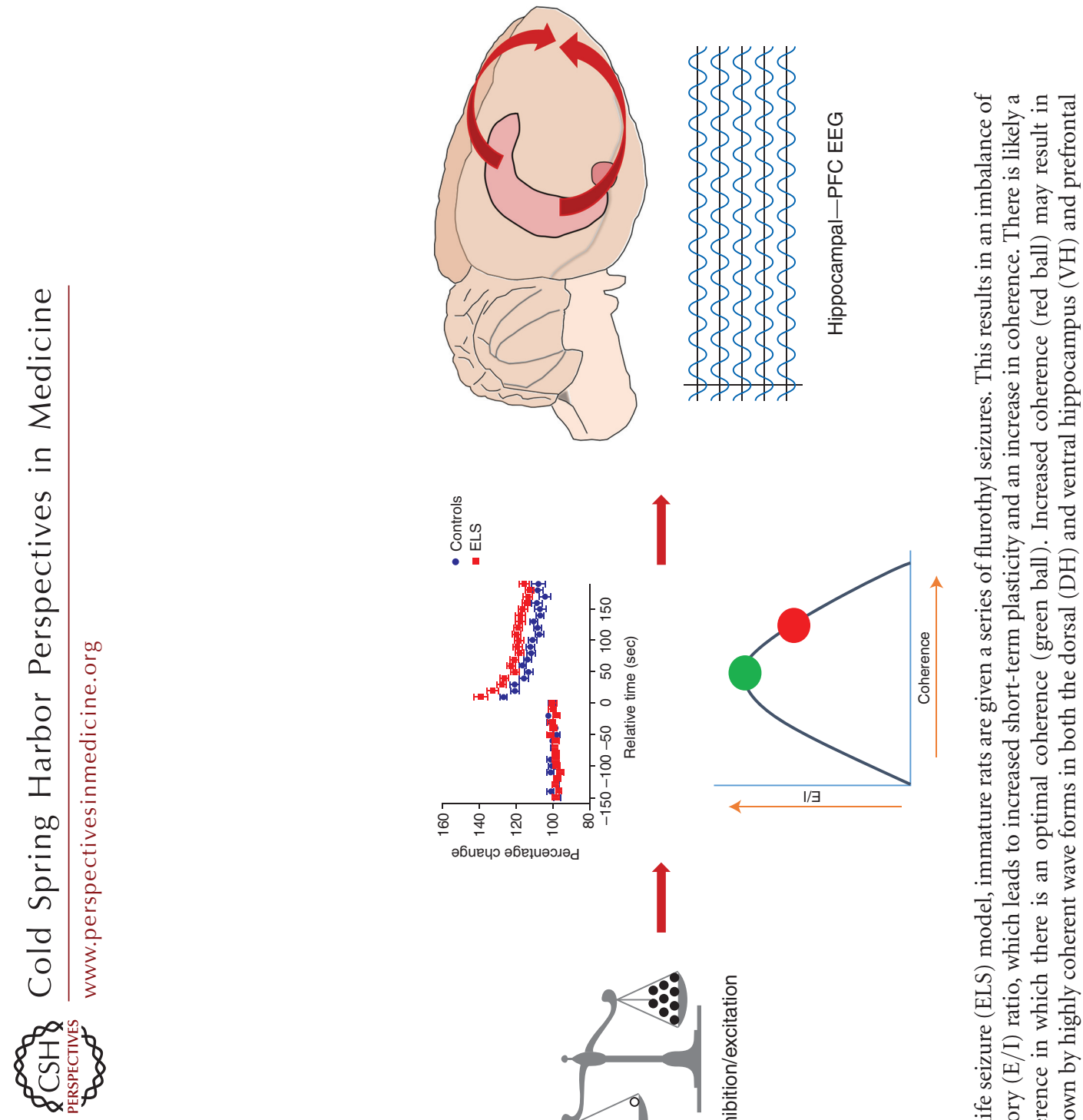

党

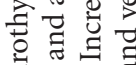

害家完

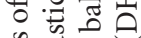

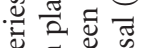

क छ

ए

कo :

जั के

范 8

플 ส

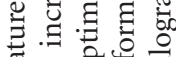

ํํㅇำ

छี च ते चे

i $\cong$.

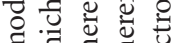

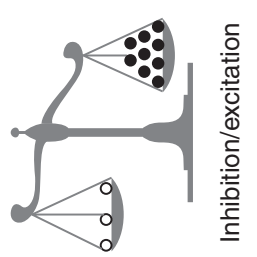

उ 80

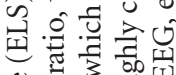

03.001

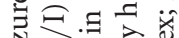

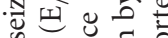

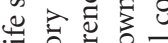

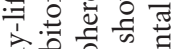

컬 0 ป

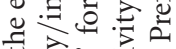

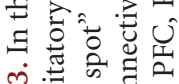

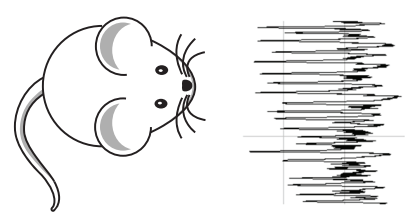

ن

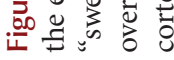


the inclusion/exclusion criteria related to ID, the regions, and even the frequencies reported vary by publication. Overall, EEG-derived coherence literature generally mirrors that obtained using MRI, in that the results are widely varied and provide evidence for both over- and underconnectivity in ASD (Luckhardt et al. 2014; Maximo et al. 2014).

It is important to note that ASD is an evolving disorder and, like changes in regional brain volume (Courchesne et al. 2011; Lange et al. 2015), brain connectivity changes with age (Cheng et al. 2010; Doyle-Thomas et al. 2015). Therefore, it is extremely important that age and developmental stage be accounted for when evaluating functional connectivity in ASD. For example, in a recent study examining age-related changes in default mode network connectivity, children with ASD showed a mixed pattern of increased and decreased connectivity between the posterior cingulate cortex and the default mode network (Doyle-Thomas et al. 2015). Importantly, in the children with ASD, connectivity between the posterior cingulate cortex and mPFC was higher than neurotypical controls in the youngest children but then decreased with age. The default mode network is a network of brain areas mostly along the midline of the brain, which is active during rest but decreases activity during externally directed, attention-demanding, cognitive tasks (Kennedy et al. 2006). This network shares many of the same regions implicated in social emotion processing and self-awareness, which are impaired in ASD (Minshew and Keller 2010).

\section{SUMMARY}

There are multiple genetic and environmental causes for both ASD and epilepsy, and both can be conceptualized as disorders of aberrant connectivity. Evidence is accumulating that the cooccurrence may be explained by the same nascent insult. For example, early life seizures may result in the altered function of neurotransmitter systems and intrinsic neuronal properties during neurodevelopment leading directly to disrupted cortical connectivity. The clinical expression of this derailment can result in seizures or devastating impairments in social communication and behavior, or both. Further investigations in animal models with both epilepsy and ALB are needed to resolve many unanswered questions regarding this important co-occurrence.

\section{ACKNOWLEDGMENTS}

This work is supported by the National Institutes of Health (NIH) Grants NS074450, NS074450, and NS073083, and the Emmory R. Shapses Research Fund and Michael J. Pietroniro Research Fund (G.L.H.).

\section{REFERENCES}

Abrahams BS, Geschwind DH. 2008. Advances in autism genetics: On the threshold of a new neurobiology. Nat Rev Genet 9: 341-355.

Akshoomoff N, Farid N, Courchesne E, Haas R. 2007. Abnormalities on the neurological examination and EEG in young children with pervasive developmental disorders. J Autism Dev Disord 37: 887-893.

Amiet C, Gourfinkel-An I, Bouzamondo A, Tordjman S Baulac M, Lechat P, Mottron L, Cohen D. 2008. Epilepsy in autism is associated with intellectual disability and gender: Evidence from a meta-analysis. Biol Psychiatry 64: $577-582$

Amir RE, Van den Veyver, I, Wan M, Tran CQ, Francke U, Zoghbi HY. 1999. Rett syndrome is caused by mutations in X-linked MECP2, encoding methyl-CpG-binding protein 2. Nat Genet 23: 185-188.

Anderson JS, Nielsen JA, Froehlich AL, Dubray MB, Druzgal TJ, Cariello AN, Cooperrider JR, Zielinski BA, Ravichandran C, Fletcher PT, et al. 2011. Functional connectivity magnetic resonance imaging classification of autism. Brain 134: 3742-3754.

Anney R, Klei L, Pinto D, Regan R, Conroy J, Magalhaes TR, Correia C, Abrahams BS, Sykes N, Pagnamenta AT, et al. 2010. A genome-wide scan for common alleles affecting risk for autism. Hum Mol Genet 19: 4072-4082.

Assogba K, Ferlazzo E, Striano P, Calarese T, Villeneuve N, Ivanov I, Bramanti P, Sessa E, Pacheva I, Genton P. 2010 Heterogeneous seizure manifestations in Hypomelanosis of Ito: Report of four new cases and review of the literature. Neurol Sci 31: 9-16.

Atallah BV, Scanziani M. 2009. Instantaneous modulation of gamma oscillation frequency by balancing excitation with inhibition. Neuron 62: 566-577.

Auerbach BD, Osterweil EK, Bear MF. 2011. Mutations causing syndromic autism define an axis of synaptic pathophysiology. Nature 480: 63-68.

Baio J. 2014. Prevalence of autism spectrum disorder among children aged 8 years-Autism and Developmental Disabilities Monitoring Network, 11 Sites, United States, 
A.W. Buckley and G.L. Holmes

2010. Centers for Disease Control and Prevention (CDC), Atlanta, GA, pp. 1-22.

Baird G, Robinson RO, Boyd S, Charman T. 2006. Sleep electroencephalograms in young children with autism with and without regression. Dev Med Child Neurol 48: 604-608.

Banihani R, Smile S, Yoon G, Dupuis A, Mosleh M, Snider A, McAdam L. 2015. Cognitive and neurobehavioral profile in boys with Duchenne muscular dystrophy. J Child Neurol doi: 10.1177/0883073815570154.

Banko JL, Poulin F, Hou L, DeMaria CT, Sonenberg N, Klann E. 2005. The translation repressor 4E-BP2 is critical for eIF4F complex formation, synaptic plasticity, and memory in the hippocampus. J Neurosci 25: 95819590.

Bao X, Downs J, Wong K, Williams S, Leonard H. 2013. Using a large international sample to investigate epilepsy in Rett syndrome. Dev Med Child Neurol 55: 553-558.

Barttfeld P, Wicker B, Cukier S, Navarta S, Lew S, Sigman M. 2011. A big-world network in ASD: Dynamical connectivity analysis reflects a deficit in long-range connections and an excess of short-range connections. Neuropsychologia 49: 254-263.

Bassell GJ, Warren ST. 2008. Fragile X syndrome: Loss of local mRNA regulation alters synaptic development and function. Neuron 60: 201-214.

Bateup HS, Takasaki KT, Saulnier JL, Denefrio CL, Sabatin BL. 2011. Loss of Tscl in vivo impairs hippocampal mGluR-LTD and increases excitatory synaptic function. J Neurosci 31: 8862-8869.

Beaudet AL. 2007. Autism: Highly heritable but not inherited. Nat Med 13: 534-536.

Ben Bashat D, Kronfeld-Duenias V, Zachor DA, Ekstein PM Hendler T, Tarrasch R, Even A, Levy Y, Ben SL. 2007. Accelerated maturation of white matter in young children with autism: A high b value DWI study. NeuroImage 37: $40-47$.

Berg AT, Plioplys S, Tuchman R. 2011. Risk and correlates of autism spectrum disorder in children with epilepsy: A community-based study. J Child Neurol 26: 540-547.

Berkvens JJ, Veugen I, Veendrick-Meekes MJ, SnoeijenSchouwenaars FM, Schelhaas HJ, Willemsen MH, Tan IY, Aldenkamp AP. 2015. Autism and behavior in adult patients with Dravet syndrome (DS). Epilepsy Behav 47: $11-16$.

Berry-Kravis E. 2002. Epilepsy in fragile X syndrome. Dev Med Child Neurol 44: 724-728.

Besag FM. 2004. Behavioral aspects of pediatric epilepsy syndromes. Epilepsy Behav 5: S3-S13.

Bombardieri R, Pinci M, Moavero R, Cerminara C, Curatolo P. 2010. Early control of seizures improves long-term outcome in children with tuberous sclerosis complex. Eur J Paediatr Neurol 14: 146-149.

Bonita JD, Ambolode LC, Rosenberg BM, Cellucci CJ, Watanabe TA, Rapp PE, Albano AM. 2014. Time domain measures of inter-channel EEG correlations: A comparison of linear, nonparametric and nonlinear measures. Cogn Neurodyn 8: 1-15.

Bosl W, Tierney A, Tager-Flusberg H, Nelson C. 2011. EEG complexity as a biomarker for autism spectrum disorder risk. BMC Med 9: 18.
Buescher AV, Cidav Z, Knapp M, Mandell DS. 2014. Costs of autism spectrum disorders in the United Kingdom and the United States. JAMA Pediatr 168: 721-728.

Buxbaum JD, Cai G, Nygren G, Chaste P, Delorme R, Goldsmith J, Rastam M, Silverman JM, Hollander E, Gillberg C, et al. 2007. Mutation analysis of the NSD1 gene in patients with autism spectrum disorders and macrocephaly. BMC Med Genet 8: 68.

Canitano R, Luchetti A, Zappella M. 2005. Epilepsy, electroencephalographic abnormalities, and regression in children with autism. J Child Neurol 20: 27-31.

Carson AM, Salowitz NM, Scheidt RA, Dolan BK, Van Hecke AV. 2014. Electroencephalogram coherence in children with and without autism spectrum disorders: Decreased interhemispheric connectivity in autism. Autism Res 7: 334-343.

Casanova M, Trippe J. 2009. Radial cytoarchitecture and patterns of cortical connectivity in autism. Philos Trans $R$ Soc Lond B Biol Sci 364: 1433-1436.

Catarino A, Andrade A, Churches O, Wagner AP, BaronCohen S, Ring H. 2013. Task-related functional connectivity in autism spectrum conditions: An EEG study using wavelet transform coherence. Mol Autism 4: 1.

Chahrour M, Zoghbi HY. 2007. The story of Rett syndrome: From clinic to neurobiology. Neuron 56: 422-437.

Chen R, Jiao Y, Herskovits EH. 2011. Structural MRI in autism spectrum disorder. Pediatr Res 69: 63R-68R.

Cheng Y, Chou KH, Chen IY, Fan YT, Decety J, Lin CP. 2010. Atypical development of white matter microstructure in adolescents with autism spectrum disorders. NeuroImage 50: $873-882$.

Cherkassky VL, Kana RK, Keller TA, Just MA. 2006. Functional connectivity in a baseline resting-state network in autism. NeuroReport 17: 1687-1690.

Chevere-Torres I, Kaphzan H, Bhattacharya A, Kang A, Maki JM, Gambello MJ, Arbiser JL, Santini E, Klann E. 2012. Metabotropic glutamate receptor-dependent long-term depression is impaired due to elevated ERK signaling in the $\Delta$ RG mouse model of tuberous sclerosis complex. Neurobiol Dis 45: 1101-1110.

Chez MG, Chang M, Krasne V, Coughlan C, Kominsky M, Schwartz A. 2006. Frequency of epileptiform EEG abnormalities in a sequential screening of autistic patients with no known clinical epilepsy from 1996 to 2005. Epilepsy Behav 8: 267-271.

Clancy B, Finlay BL, Darlington RB, Anand KJ. 2007. Extrapolating brain development from experimental species to humans. Neurotoxicology 28: 931-937.

Clement JP, Aceti M, Creson TK, Ozkan ED, Shi Y, Reish NJ, Almonte AG, Miller BH, Wiltgen BJ, Miller CA, et al. 2012. Pathogenic SYNGAP1 mutations impair cognitive development by disrupting maturation of dendritic spine synapses. Cell 151: 709-723.

Coben R, Clarke AR, Hudspeth W, Barry RJ. 2008. EEG power and coherence in autistic spectrum disorder Clin Neurophysiol 119: 1002-1009.

Cordelli DM, Garavelli L, Savasta S, Guerra A, Pellicciari A, Giordano L, Bonetti S, Cecconi I, Wischmeijer A, Seri M, et al. 2013. Epilepsy in Mowat-Wilson syndrome: Delineation of the electroclinical phenotype. Am J Med Genet A 161A: 273-284. 
Costa-Mattioli M, Gobert D, Harding H, Herdy B, Azzi M, Bruno M, Bidinosti M, Ben MC, Marcinkiewicz E, Yoshida M, et al. 2005. Translational control of hippocampal synaptic plasticity and memory by the eIF $2 \alpha$ kinase GCN2. Nature 436: 1166-1173.

Courchesne E. 2002. Abnormal early brain development in autism. Mol Psychiatry 7: S21-S23.

Courchesne E. 2004. Brain development in autism: Early overgrowth followed by premature arrest of growth. Ment Retard Dev Disabil Res Rev 10: 106-111.

Courchesne E, Carper R, Akshoomoff N. 2003. Evidence of brain overgrowth in the first year of life in autism. JAMA 290: $337-344$

Courchesne E, Redcay E, Morgan JT, Kennedy DP. 2005. Autism at the beginning: Microstructural and growth abnormalities underlying the cognitive and behavioral phenotype of autism. Dev Psychopathol 17: 577-597.

Courchesne E, Campbell K, Solso S. 2011. Brain growth across the life span in autism: Age-specific changes in anatomical pathology. Brain Res 1380: 138-145.

Crino PB, Nathanson KL, Henske EP. 2006. The tuberous sclerosis complex. N Engl J Med 355: 1345-1356.

Curatolo P, Moavero R, de Vries PJ. 2015. Neurological and neuropsychiatric aspects of tuberous sclerosis complex. Lancet Neurol 14: 733-745.

Cusmai R, Moavero R, Bombardieri R, Vigevano F, Curatolo P. 2011. Long-term neurological outcome in children with early-onset epilepsy associated with tuberous sclerosis. Epilepsy Behav 22: 735-739.

Danielsson S, Gillberg IC, Billstedt E, Gillberg C, Olsson I. 2005. Epilepsy in young adults with autism: A prospective population-based follow-up study of 120 individuals diagnosed in childhood. Epilepsia 46: 918-923.

DiGuiseppi C, Hepburn S, Davis JM, Fidler DJ, Hartway S, Lee NR, Miller L, Ruttenber M, Robinson C. 2010. Screening for autism spectrum disorders in children with Down syndrome: Population prevalence and screening test characteristics. J Dev Behav Pediatr 31: 181-191.

Dinstein I, Pierce K, Eyler L, Solso S, Malach R, Behrmann M, Courchesne E. 2011. Disrupted neural synchronization in toddlers with autism. Neuron 70: 1218-1225.

Dolen G, Bear MF. 2008. Role for metabotropic glutamate receptor 5 (mGluR5) in the pathogenesis of fragile $\mathrm{X}$ syndrome. J Physiol 586: 1503-1508.

Doyle-Thomas KA, Lee W, Foster NE, Tryfon A, Ouimet T, Hyde KL, Evans AC, Lewis J, Zwaigenbaum L, Anagnostou E. 2015. Atypical functional brain connectivity during rest in autism spectrum disorders. Ann Neurol 77: 866-876.

Duffy FH, Als H. 2012. A stable pattern of EEG spectral coherence distinguishes children with autism from neuro-typical controls-A large case control study. BMC Med 10: 64.

Eeg-Olofsson O, Petersén I, Selldén U. 1971. The development of the electroencephalogram in normal children from the age of 1 through 15 years: Paroxysmal activity. Neuropädiatrie 2: 375-404.

Ehninger D, Han S, Shilyansky C, Zhou Y, Li W, Kwiatkowski DJ, Ramesh V, Silva AJ. 2008. Reversal of learning deficits in a $T s c 2^{+/-}$mouse model of tuberous sclerosis. Nat Med 14: 843-848.
Elia M, Musumeci SA, Ferri R, Bergonzi P. 1995. Clinical and neurophysiological aspects of epilepsy in subjects with autism and mental retardation. Am J Ment Retard 100: 6-16.

Evans E, Einfeld S, Mowat D, Taffe J, Tonge B, Wilson M. 2012. The behavioral phenotype of Mowat-Wilson syndrome. Am J Med Genet A 158A: 358-366.

Fenelon K, Xu B, Lai CS, Mukai J, Markx S, Stark KL, Hsu PK, Gan WB, Fischbach GD, MacDermott AB, et al. 2013. The pattern of cortical dysfunction in a mouse model of a schizophrenia-related microdeletion. J Neurosci 33: 14825-14839.

Fiumara A, Pittala A, Cocuzza M, Sorge G. 2010. Epilepsy in patients with Angelman syndrome. Ital J Pediatr 36: 31.

Gabis L, Pomeroy J, Andriola MR. 2005. Autism and epilepsy: Cause, consequence, comorbidity, or coincidence? Epilepsy Behav 7: 652-656.

Garcia Dominguez L, Stieben J, Perez Velazquez JL, Shanker S. 2013. The imaginary part of coherency in autism: Differences in cortical functional connectivity in preschool children. PLoS ONE 8: e75941.

Garcia-Nonell C, Ratera ER, Harris S, Hessl D, Ono MY, Tartaglia N, Marvin E, Tassone F, Hagerman RJ. 2008. Secondary medical diagnosis in fragile $\mathrm{X}$ syndrome with and without autism spectrum disorder. Am J Med Genet A 146A: 1911-1916.

Gaugler T, Klei L, Sanders SJ, Bodea CA, Goldberg AP, Lee AB, Mahajan M, Manaa D, Pawitan Y, Reichert J, et al. 2014. Most genetic risk for autism resides with common variation. Nat Genet 46: 881-885.

Geerts A, Brouwer O, van DC, Stroink H, Peters B, Peeters E, Arts WF. 2011. Health perception and socioeconomic status following childhood-onset epilepsy: The Dutch study of epilepsy in childhood. Epilepsia 52: 2192-2202.

Geschwind DH. 2008. Autism: Many genes, common pathways? Cell 135: 391-395.

Giannotti F, Cortesi F, Cerquiglini A, Miraglia D, Vagnoni C, Sebastiani T, Bernabei P. 2008. An investigation of sleep characteristics, EEG abnormalities and epilepsy in developmentally regressed and non-regressed children with autism. J Autism Dev Disord 38: 1888-1897.

Gilboa T, Gross-Tsur V. 2013. Epilepsy in Prader-Willi syndrome: Experience of a national referral centre. Dev Med Child Neurol 55: 857-861.

Giovanardi RP, Posar A, Parmeggiani A. 2000. Epilepsy in adolescents and young adults with autistic disorder. Brain Dev 22: 102-106.

Goldberg-Stern H, Strawsburg RH, Patterson B, Hickey F, Bare M, Gadoth N, Degrauw TJ. 2001. Seizure frequency and characteristics in children with Down syndrome. Brain Dev 23: 375-378.

Goldman AM, Potocki L, Walz K, Lynch JK, Glaze DG, Lupski JR, Noebels JL. 2006. Epilepsy and chromosomal rearrangements in Smith-Magenis syndrome [del(17) (p11.2p11.2)]. J Child Neurol 21: 93-98.

Hallmayer J, Cleveland S, Torres A, Phillips J, Cohen B, Torigoe T, Miller J, Fedele A, Collins J, Smith K, et al. 2011. Genetic heritability and shared environmental factors among twin pairs with autism. Arch Gen Psychiatry 68: $1095-1102$. 
A.W. Buckley and G.L. Holmes

Hara H. 2007. Autism and epilepsy: A retrospective followup study. Brain Dev 29: 486-490.

Hashimoto T, Sasaki M, Sugai K, Hanaoka S, Fukumizu M, Kato T. 2001. Paroxysmal discharges on EEG in young autistic patients are frequent in frontal regions. $J$ Med Invest 48: 175-180.

Hernan AE, Holmes GL, Isaev D, Scott RC, Isaeva E. 2013. Altered short-term plasticity in the prefrontal cortex after early life seizures. Neurobiol Dis 50: 120-126.

Holmes GL, Stafstrom CE. 2007. Tuberous sclerosis complex and epilepsy: Recent developments and future challenges. Epilepsia 48: 617-630.

Holmes GL, Tian C, Hernan AE, Camp D, Flynn S, Barry J. 2015. Alterations in sociability and functional brain connectivity caused by early-life seizures is reversed by bumetanide. Neurobiol Dis 77: 204-219.

Hrdlicka M, Komarek V, Propper L, Kulisek R, Zumrova A, Faladova L, Havlovicova M, Sedlacek Z, Blatny M, Urbanek T. 2004. Not EEG abnormalities but epilepsy is associated with autistic regression and mental functioning in childhood autism. Eur Child Adolesc Psychiatry 13: 209-213.

Hughes JR, Melyn M. 2005. EEG and seizures in autistic children and adolescents: Further findings with therapeutic implications. Clin EEG Neurosci 36: 15-20.

Hughes R, Poon WY, Harvey AS. 2015. Limited role for routine EEG in the assessment of staring in children with autism spectrum disorder. Arch Dis Child 100: $30-33$.

Isaeva E, Isaev D, Khazipov R, Holmes GL. 2009. Long-term suppression of GABAergic activity by neonatal seizures in rat somatosensory cortex. Epilepsy Res 87: 286-289.

Isaeva E, Isaev D, Savrasova A, Khazipov R, Holmes GL. 2010. Recurrent neonatal seizures result in long-term increases in neuronal network excitability in the rat neocortex. Eur J Neurosci 31: 1446-1455.

Isler JR, Martien KM, Grieve PG, Stark RI, Herbert MR. 2010. Reduced functional connectivity in visual evoked potentials in children with autism spectrum disorder. Clin Neurophysiol 121: 2035-2043.

Just MA, Cherkassky VL, Keller TA, Kana RK, Minshew NJ. 2007. Functional and anatomical cortical underconnectivity in autism: Evidence from an fMRI study of an executive function task and corpus callosum morphometry. Cereb Cortex 17: 951-961.

Kana RK, Keller TA, Cherkassky VL, Minshew NJ, Just MA. 2006. Sentence comprehension in autism: Thinking in pictures with decreased functional connectivity. Brain 129: $2484-2493$.

Kana RK, Libero LE, Moore MS. 2011. Disrupted cortical connectivity theory as an explanatory model for autism spectrum disorders. Phys Life Rev 8: 410-437.

Kanner L. 1968. Autistic disturbances of affective contact. Acta Paedopsychiatr 35: 100-136.

Kennedy DP, Redcay E, Courchesne E. 2006. Failing to deactivate: Resting functional abnormalities in autism. Proc Natl Acad Sci 103: 8275-8280.

Keown CL, Shih P, Nair A, Peterson N, Mulvey ME, Muller RA. 2013. Local functional overconnectivity in posterior brain regions is associated with symptom severity in autism spectrum disorders. Cell Rep 5: 567-572.
Khan S, Gramfort A, Shetty NR, Kitzbichler MG, Ganesan S, Moran JM, Lee SM, Gabrieli JD, Tager-Flusberg HB, Joseph RM, et al. 2013. Local and long-range functional connectivity is reduced in concert in autism spectrum disorders. Proc Natl Acad Sci 110: 3107-3112.

Kim HL, Donnelly JH, Tournay AE, Book TM, Filipek P. 2006. Absence of seizures despite high prevalence of epileptiform EEG abnormalities in children with autism monitored in a tertiary care center. Epilepsia 47: 394398.

Kleen JK, Sesque A, Wu EX, Miller FA, Hernan AE, Holmes GL, Scott RC. 2011a. Early-life seizures produce lasting alterations in the structure and function of the prefrontal cortex. Epilepsy Behav 22: 214-219.

Kleen JK, Wu EX, Holmes GL, Scott RC, Lenck-Santini PP. 2011b. Enhanced oscillatory activity in the hippocampalprefrontal network is related to short-term memory function after early-life seizures. J Neurosci 31: 1539715406.

Kohane IS, McMurry A, Weber G, MacFadden D, Rappaport L, Kunkel L, Bickel J, Wattanasin N, Spence S, Murphy S, et al. 2012. The co-morbidity burden of children and young adults with autism spectrum disorders. PLOS ONE 7: e33224.

Kolevzon A, Angarita B, Bush L, Wang AT, Frank Y, Yang A, Rapaport R, Saland J, Srivastava S, Farrell C, et al. 2014 Phelan-McDermid syndrome: A review of the literature and practice parameters for medical assessment and monitoring. J Neurodev Disord 6: 39.

Koshino H, Carpenter PA, Minshew NJ, Cherkassky VL, Keller TA, Just MA. 2005. Functional connectivity in an fMRI working memory task in high-functioning autism. NeuroImage 24: 810-821.

Koshino H, Kana RK, Keller TA, Cherkassky VL, Minshew NJ, Just MA. 2008. fMRI investigation of working memory for faces in autism: Visual coding and underconnectivity with frontal areas. Cereb Cortex 18: 289-300.

Laje G, Morse R, Richter W, Ball J, Pao M, Smith AC. 2010. Autism spectrum features in Smith-Magenis syndrome. Am J Med Genet C Semin Med Genet 154C: 456-462.

Lange N, Travers BG, Bigler ED, Prigge MB, Froehlich AL, Nielsen JA, Cariello AN, Zielinski BA, Anderson JS, Fletcher PT, et al. 2015. Longitudinal volumetric brain changes in autism spectrum disorder ages $6-35$ years. Autism Res 8: 82-93.

Laplante M, Sabatini DM. 2012. mTOR signaling in growth control and disease. Cell 149: 274-293.

Lazar AS, Lazar ZI, Biro A, Gyori M, Tarnok Z, Prekop C, Keszei A, Stefanik K, Gadoros J, Halasz P, Bodizs R. 2010. Reduced fronto-cortical brain connectivity during NREM sleep in Asperger syndrome: An EEG spectral and phase coherence study. Clin Neurophysiol 121: 1844-1854.

Lazarev VV, Pontes A, Mitrofanov AA, deAzevedo LC. 2010. Interhemispheric asymmetry in EEG photic driving coherence in childhood autism. Clin Neurophysiol 121: $145-152$.

Lazarev VV, Pontes A, Mitrofanov AA, deAzevedo LC. 2015. Reduced interhemispheric connectivity in childhood autism detected by electroencephalographic photic driving coherence. J Autism Dev Disord 45: 537-547. 
Leveille J, Hannagan T. 2013. Learning spatial invariance with the trace rule in nonuniform distributions. Neural Comput 25: 1261-1276.

Leveille C, Barbeau EB, Bolduc C, Limoges E, Berthiaume C, Chevrier E, Mottron L, Godbout R. 2010. Enhanced connectivity between visual cortex and other regions of the brain in autism: An REM sleep EEG coherence study. Autism Res 3: 280-285.

Lewis JD, Theilmann RJ, Townsend J, Evans AC. 2013. Network efficiency in autism spectrum disorder and its relation to brain overgrowth. Front Hum Neurosci 7: 845.

Li BM, Liu XR, Yi YH, Deng YH, Su T, Zou X, Liao WP. 2011 Autism in Dravet syndrome: Prevalence, features, and relationship to the clinical characteristics of epilepsy and mental retardation. Epilepsy Behav 21: 291-295.

Lowenthal R, Paula CS, Schwartzman JS, Brunoni D, Mercadante MT. 2007. Prevalence of pervasive developmental disorder in Down's syndrome. J Autism Dev Disord 37: 1394-1395.

Luckhardt C, Jarczok TA, Bender S. 2014. Elucidating the neurophysiological underpinnings of autism spectrum disorder: New developments. J Neural Transm 121: 1129-1144.

Lugo JN, Swann JW, Anderson AE. 2014. Early-life seizures result in deficits in social behavior and learning. Exp Neurol 256: 74-80.

Machado C, Estevez M, Leisman G, Melillo R, Rodriguez R, DeFina P, Hernandez A, Perez-Nellar J, Naranjo R, Chinchilla M, et al. 2015. QEEG spectral and coherence assessment of autistic children in three different experimental conditions. J Autism Dev Disord 45: 406-424.

Mathewson KJ, Jetha MK, Drmic IE, Bryson SE, Goldberg JO, Schmidt LA. 2012. Regional EEG alpha power, coherence, and behavioral symptomatology in autism spectrum disorder. Clin Neurophysiol 123: 1798-1809.

Matsuo M, Maeda T, Sasaki K, Ishii K, Hamasaki Y. 2010. Frequent association of autism spectrum disorder in patients with childhood onset epilepsy. Brain Dev 32: 759 763.

Matsuo M, Maeda T, Ishii K, Tajima D, Koga M, Hamasaki Y. 2011. Characterization of childhood-onset complex partial seizures associated with autism spectrum disorder Epilepsy Behav 20: 524-527.

Maximo JO, Cadena EJ, Kana RK. 2014. The implications of brain connectivity in the neuropsychology of autism. Neuropsychol Rev 24: 16-31.

Meikle L, Pollizzi K, Egnor A, Kramvis I, Lane H, Sahin M, Kwiatkowski DJ. 2008. Response of a neuronal model of tuberous sclerosis to mammalian target of rapamycin (mTOR) inhibitors: Effects on mTORC1 and Akt signaling lead to improved survival and function. $J$ Neurosci 28: $5422-5432$.

Miles JH. 2011. Autism spectrum disorders-A genetics review. Genet Med 13: 278-294

Mines MA, Yuskaitis CJ, King MK, Beurel E, Jope RS. 2010. GSK3 influences social preference and anxiety-related behaviors during social interaction in a mouse model of fragile X syndrome and autism. PLoS ONE 5: e9706.

Minshew NJ, Keller TA. 2010. The nature of brain dysfunction in autism: Functional brain imaging studies. Curr Opin Neurol 23: 124-130.
Molloy CA, Murray DS, Kinsman A, Castillo H, Mitchell T, Hickey FJ, Patterson B. 2009. Differences in the clinical presentation of Trisomy 21 with and without autism. J Intellect Disabil Res 53: 143-151.

Moss JF, Oliver C, Berg K, Kaur G, Jephcott L, Cornish K. 2008. Prevalence of autism spectrum phenomenology in Cornelia de Lange and Cri du Chat syndromes. Am J Ment Retard 113: 278-291.

Moss J, Howlin P, Magiati I, Oliver C. 2012. Characteristics of autism spectrum disorder in Cornelia de Lange syndrome. J Child Psychol Psychiatry 53: 883-891.

Mouridsen SE, Hansen MB. 2002. Neuropsychiatric aspects of Sotos syndrome. A review and two case illustrations. Eur Child Adolesc Psychiatry 11: 43-48.

Muller RA, Shih P, Keehn B, Deyoe JR, Leyden KM, Shukla DK. 2011. Underconnected, but how? A survey of functional connectivity MRI studies in autism spectrum disorders. Cereb Cortex 21: 2233-2243.

Murias M, Webb SJ, Greenson J, Dawson G. 2007. Resting state cortical connectivity reflected in EEG coherence in individuals with autism. Biol Psychiatry 62: 270-273.

Numis AL, Major P, Montenegro MA, Muzykewicz DA Pulsifer MB, Thiele EA. 2011. Identification of risk factors for autism spectrum disorders in tuberous sclerosis complex. Neurology 76: 981-987.

Oliver C, Arron K, Sloneem J, Hall S. 2008. Behavioural phenotype of Cornelia de Lange syndrome: Case-control study. Br J Psychiatry 193: 466-470.

Olsson I, Steffenburg S, Gillberg C. 1988. Epilepsy in autism and autisticlike conditions. A population-based study. Arch Neurol 45: 666-668.

Orekhova EV, Elsabbagh M, Jones EJ, Dawson G, Charman T, Johnson MH. 2014. EEG hyper-connectivity in highrisk infants is associated with later autism. J Neurodev Disord 6: 40.

Ozkan ED, Creson TK, Kramar EA, Rojas C, Seese RR, Babyan AH, Shi Y, Lucero R, Xu X, Noebels JL, et al. 2014. Reduced cognition in Syngapl mutants is caused by isolated damage within developing forebrain excitatory neurons. Neuron 82: 1317-1333.

Paemka L, Mahajan VB, Skeie JM, Sowers LP, Ehaideb SN, Gonzalez-Alegre P, Sasaoka T, Tao H, Miyagi A, Ueno N, et al. 2013. PRICKLE1 interaction with SYNAPSIN I reveals a role in autism spectrum disorders. PLOS ONE 8: e80737.

Paemka L, Mahajan VB, Ehaideb SN, Skeie JM, Tan MC, Wu S, Cox AJ, Sowers LP, Gecz J, Jolly L, et al. 2015. Seizures are regulated by ubiquitin-specific peptidase $9 \mathrm{X}$-linked (USP9X), a de-ubiquitinase. PLoS Genet 11: e1005022.

Pane M, Messina S, Bruno C, D'Amico A, Villanova M, Brancalion B, Sivo S, Bianco F, Striano P, Battaglia D, et al. 2013. Duchenne muscular dystrophy and epilepsy. Neuromuscul Disord 23: 313-315.

Parmeggiani A, Posar A, Antolini C, Scaduto MC, Santucci M, Giovanardi-Rossi P. 2007. Epilepsy in patients with pervasive developmental disorder not otherwise specified. J Child Neurol 22: 1198-1203.

Pascual-Castroviejo I, Roche C, Martinez-Bermejo A, Arcas J, Lopez-Martin V, Tendero A, Esquiroz JL, Pascual-Pascual SI. 1998. Hypomelanosis of ITO. A study of 76 infantile cases. Brain Dev 20: 36-43. 
A.W. Buckley and G.L. Holmes

Pavlidis E, Cantalupo G, Bianchi S, Piccolo B, Pisani F. 2014 Epileptic features in Cornelia de Lange syndrome: Case report and literature review. Brain Dev 36: 837-843.

Paz JT, Davidson TJ, Frechette ES, Delord B, Parada I, Peng K, Deisseroth K, Huguenard JR. 2013. Closed-loop optogenetic control of thalamus as a tool for interrupting seizures after cortical injury. Nat Neurosci 16: 64-70.

Penagarikano O, Abrahams BS, Herman EI, Winden KD, Gdalyahu A, Dong H, Sonnenblick LI, Gruver R, Almajano J, Bragin A, et al. 2011. Absence of CNTNAP2 leads to epilepsy, neuronal migration abnormalities, and core autism-related deficits. Cell 147: 235-246.

Percy AK. 2011. Rett syndrome: Exploring the autism link. Arch Neurol 68: 985-989.

Peters SU, Beaudet AL, Madduri N, Bacino CA. 2004. Autism in Angelman syndrome: Implications for autism research. Clin Genet 66: 530-536.

Peters JM, Taquet M, Vega C, Jeste SS, Fernandez IS, Tan J, Nelson CA, III, Sahin M, Warfield SK. 2013. Brain functional networks in syndromic and non-syndromic autism: A graph theoretical study of EEG connectivity. BMC Med 11: 54 .

Pina-Camacho L, Villero S, Fraguas D, Boada L, Janssen J, Navas-Sanchez FJ, Mayoral M, Llorente C, Arango C, Parellada M. 2012. Autism spectrum disorder: Does neuroimaging support the DSM-5 proposal for a symptom dyad? A systematic review of functional magnetic resonance imaging and diffusion tensor imaging studies. $J$ Autism Dev Disord 42: 1326-1341.

Pinto D, Delaby E, Merico D, Barbosa M, Merikangas A, Klei L, Thiruvahindrapuram B, Xu X, Ziman R, Wang Z, et al. 2014. Convergence of genes and cellular pathways dysregulated in autism spectrum disorders. Am J Hum Genet 94: 677-694.

Reilly C, Atkinson P, Das KB, Chin RF, Aylett SE, Burch V, Gillberg C, Scott RC, Neville BG. 2014. Screening for mental health disorders in active childhood epilepsy: Population-based data. Epilepsy Res 108: 1917-1926.

Reilly C, Atkinson P, Das KB, Chin RF, Aylett SE, Burch V, Gillberg C, Scott RC, Neville BG. 2015. Features of autism spectrum disorder (ASD) in childhood epilepsy: A population-based study. Epilepsy Behav 42: 86-92.

Righi G, Tierney AL, Tager-Flusberg H, Nelson CA. 2014. Functional connectivity in the first year of life in infants at risk for autism spectrum disorder: An EEG study. PLoS ONE 9: e105176.

Risch N, Spiker D, Lotspeich L, Nouri N, Hinds D, Hallmayer J, Kalaydjieva L, McCague P, Dimiceli S, Pitts T, et al. 1999. A genomic screen of autism: Evidence for a multilocus etiology. Am J Hum Genet 65: 493-507.

Ruggieri M, Pavone L. 2000. Hypomelanosis of Ito: Clinical syndrome or just phenotype? J Child Neurol 15: 635-644.

Saemundsen E, Ludvigsson P, Hilmarsdottir I, Rafnsson V. 2007. Autism spectrum disorders in children with seizures in the first year of life-A population-based study. Epilepsia 48: 1724-1730.

Saemundsen E, Ludvigsson P, Rafnsson V. 2008. Risk of autism spectrum disorders after infantile spasms: A population-based study nested in a cohort with seizures in the first year of life. Epilepsia 49: 1865-1870.
Saemundsen E, Magnusson P, Georgsdottir I, Egilsson E, Rafnsson V. 2013. Prevalence of autism spectrum disorders in an Icelandic birth cohort. BMJ Open 3: e002748.

Sanders SJ, Ercan-Sencicek AG, Hus V, Luo R, Murtha MT, Moreno-De-Luca D, Chu SH, Moreau MP, Gupta AR, Thomson SA, et al. 2011. Multiple recurrent de novo CNVs, including duplications of the 7q11.23 Williams syndrome region, are strongly associated with autism. Neuron 70: 863-885.

Sarasua SM, Boccuto L, Sharp JL, Dwivedi A, Chen CF, Rollins JD, Rogers RC, Phelan K, DuPont BR. 2014. Clinical and genomic evaluation of 201 patients with PhelanMcDermid syndrome. Hum Genet 133: 847-859.

Selassie AW, Wilson DA, Martz GU, Smith GG, Wagner JL, Wannamaker BB. 2014. Epilepsy beyond seizure: A population-based study of comorbidities. Epilepsy Res 108: 305-315.

Schreiber JM, Lanham DC, Trescher WH, Sparks SE, Wassif CA, Caffo BS, Porter FD, Tierney E, Gropman AL, Ewen JB. 2014. Variations in EEG discharges predict ADHD severity within individual Smith-Lemli-Opitz patients. Neurology 83: 151-159.

Sheikhani A, Behnam H, Mohammadi MR, Noroozian M, Mohammadi M. 2012. Detection of abnormalities for diagnosing of children with autism disorders using of quantitative electroencephalography analysis. J Med Syst 36: $957-963$.

Sigurdsson T, Stark KL, Karayiorgou M, Gogos JA, Gordon JA. 2010. Impaired hippocampal-prefrontal synchrony in a genetic mouse model of schizophrenia. Nature 464: $763-767$.

Spence SJ, Schneider MT. 2009. The role of epilepsy and epileptiform EEGs in autism spectrum disorders. Pediatr Res 65: 599-606.

Steffenburg S, Gillberg C, Steffenburg U. 1996. Psychiatric disorders in children and adolescents with mental retardation and active epilepsy. Arch Neurol 53: 904-912.

Strauss KA, Puffenberger EG, Huentelman MJ, Gottlieb S, Dobrin SE, Parod JM, Stephan DA, Morton DH. 2006. Recessive symptomatic focal epilepsy and mutant contactin-associated protein-like 2. N Engl J Med 354: $1370-1377$.

Sudhof TC. 2008. Neuroligins and neurexins link synaptic function to cognitive disease. Nature 455: 903-911.

Supekar K, Uddin LQ, Khouzam A, Phillips J, Gaillard WD, Kenworthy LE, Yerys BE, Vaidya CJ, Menon V. 2013. Brain hyperconnectivity in children with autism and its links to social deficits. Cell Rep 5: 738-747.

Sweatt JD. 2013. Pitt-Hopkins syndrome: Intellectual disability due to loss of TCF4-regulated gene transcription. Exp Mol Med 45: e21.

Tatton-Brown K, Rahman N. 2004. Clinical features of NSD1-positive Sotos syndrome. Clin Dysmorphol 13: 199-204.

Tavazoie SF, Alvarez VA, Ridenour DA, Kwiatkowski DJ, Sabatini BL. 2005. Regulation of neuronal morphology and function by the tumor suppressors Tsc1 and Tsc2. Nat Neurosci 8: 1727-1734.

Thatcher RW. 2012. Coherence, phase differences, phase shift, and phase lock in EEG/ERP analyses. Dev Neuropsychol 37: 476-496. 
Tierney E, Nwokoro NA, Porter FD, Freund LS, Ghuman JK, Kelley RI. 2001. Behavior phenotype in the RSH/SmithLemli-Opitz syndrome. Am J Med Genet 98: 191-200.

Tsai PT, Hull C, Chu Y, Greene-Colozzi E, Sadowski AR, Leech JM, Steinberg J, Crawley JN, Regehr WG, Sahin M. 2012. Autistic-like behaviour and cerebellar dysfunction in Purkinje cell Tscl mutant mice. Nature 488: 647-651.

Tuchman R, Cuccaro M. 2011. Epilepsy and autism: Neurodevelopmental perspective. Curr Neurol Neurosci Rep 11: $428-434$.

Tuchman R, Rapin I. 2002. Epilepsy in autism. Lancet Neurol 1: 352-358.

Tuchman R, Hirtz D, Mamounas LA. 2013. NINDS epilepsy and autism spectrum disorders workshop report. $\mathrm{Neu}$ rology 81: 1630-1636.

Turner G, Webb T, Wake S, Robinson H. 1996. Prevalence of fragile X syndrome. Am J Med Genet 64: 196-197.

Tyzio R, Nardou R, Ferrari DC, Tsintsadze T, Shahrokhi A, Eftekhari S, Khalilov I, Tsintsadze V, Brouchoud C, Chazal G, et al. 2014. Oxytocin-mediated GABA inhibition during delivery attenuates autism pathogenesis in rodent offspring. Science 343: 675-679.

Valente KD, Koiffmann CP, Fridman C, Varella M, Kok F Andrade JQ, Grossmann RM, Marques-Dias MJ. 2006. Epilepsy in patients with angelman syndrome caused by deletion of the chromosome 15q11-13. Arch Neurol 63: 122-128.

van Eeghen AM, Pulsifer MB, Merker VL, Neumeyer AM, van Eeghen EE, Thibert RL, Cole AJ, Leigh FA, Plotkin SR, Thiele EA. 2013. Understanding relationships between autism, intelligence, and epilepsy: A cross-disorder approach. Dev Med Child Neurol 55: 146-153.

Varela F, Lachaux JP, Rodriguez E, Martinerie J. 2001. The brainweb: Phase synchronization and large-scale integration. Nat Rev Neurosci 2: 229-239.

Veltman MW, Craig EE, Bolton PF. 2005. Autism spectrum disorders in Prader-Willi and Angelman syndromes: A systematic review. Psychiatr Genet 15: 243-254.

Vendrame M, Maski KP, Chatterjee M, Heshmati A, Krishnamoorthy K, Tan WH, Kothare SV. 2010. Epilepsy in Prader-Willi syndrome: Clinical characteristics and correlation to genotype. Epilepsy Behav 19: 306-310.

Verrotti A, Cusmai R, Nicita F, Pizzolorusso A, Elia M, Zamponi N, Cesaroni E, Granata T, De Giorgi I, Giordano L, et al. 2013. Electroclinical features and long-term outcome of cryptogenic epilepsy in children with Down syndrome. J Pediatr 163: 1754-1758.
Viscidi EW, Triche EW, Pescosolido MF, McLean RL, Joseph RM, Spence SJ, Morrow EM. 2013. Clinical characteristics of children with autism spectrum disorder and cooccurring epilepsy. PLoS ONE 8: e67797.

Voineagu I, Wang X, Johnston P, Lowe JK, Tian Y, Horvath S, Mill J, Cantor RM, Blencowe BJ, Geschwind DH. 2011. Transcriptomic analysis of autistic brain reveals convergent molecular pathology. Nature 474: 380-384.

Walsh CA, Morrow EM, Rubenstein JL. 2008. Autism and brain development. Cell 135: 396-400.

Wang K, Zhang H, Ma D, Bucan M, Glessner JT, Abrahams BS, Salyakina D, Imielinski M, Bradfield JP, Sleiman PM, et al. 2009. Common genetic variants on $5 \mathrm{p} 14.1$ associate with autism spectrum disorders. Nature 459: 528-533.

Wiznitzer M. 2004. Autism and tuberous sclerosis. J Child Neurol 19: 675-679.

Weng SJ, Wiggins JL, Peltier SJ, Carrasco M, Risi S, Lord C, Monk CS. 2010. Alterations of resting state functional connectivity in the default network in adolescents with autism spectrum disorders. Brain Res 1313: 202-214.

Wheeler AC, Mussey J, Villagomez A, Bishop E, Raspa M, Edwards A, Bodfish J, Bann C, Bailey DB Jr. 2015. DSM-5 changes and the prevalence of parent-reported autism spectrum symptoms in Fragile X syndrome. J Autism Dev Disord 45: 816-829.

Wolff M, Casse-Perrot C, Dravet C. 2006. Severe myoclonic epilepsy of infants (Dravet syndrome): Natural history and neuropsychological findings. Epilepsia 47: 45-48.

Woolfenden S, Sarkozy V, Ridley G, Coory M, Williams K. 2012. A systematic review of two outcomes in autism spectrum disorder-Epilepsy and mortality. Dev Med Child Neurol 54: 306-312.

Workman AD, Charvet CJ, Clancy B, Darlington RB, Finlay BL. 2013. Modeling transformations of neurodevelopmental sequences across mammalian species. J Neurosci 33: $7368-7383$.

Yizhar O, Fenno LE, Prigge M, Schneider F, Davidson TJ, O'Shea DJ, Sohal VS, Goshen I, Finkelstein J, Paz JT, et al. 2011. Neocortical excitation/inhibition balance in information processing and social dysfunction. Nature 477: 171-178.

Young DM, Schenk AK, Yang SB, Jan YN, Jan LY. 2010. Altered ultrasonic vocalizations in a tuberous sclerosis mouse model of autism. Proc Natl Acad Sci 107: 11074-11079.

Zappella M. 1993. Autism and hypomelanosis of Ito in twins. Dev Med Child Neurol 35: 826-832.

Zoghbi HY. 2003. Postnatal neurodevelopmental disorders: Meeting at the synapse? Science 302: 826-830. 


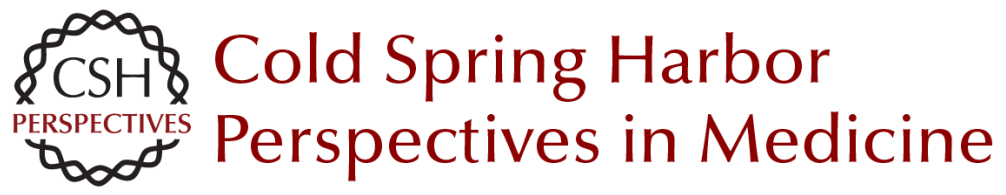

\section{Epilepsy and Autism}

Ashura W. Buckley and Gregory L. Holmes

Cold Spring Harb Perspect Med 2016; doi: 10.1101/cshperspect.a022749 originally published online March 17, 2016

\section{Subject Collection Epilepsy: The Biology of a Spectrum Disorder}

The Epilepsy Spectrum: Targeting Future Research Challenges

Gregory L. Holmes and Jeffrey L. Noebels

Role of Sodium Channels in Epilepsy

David I. Kaplan, Lori L. Isom and Steven Petrou

\section{Mechanisms of Action of Antiseizure Drugs and the Ketogenic Diet \\ Michael A. Rogawski, Wolfgang Löscher and Jong M. Rho}

Epilepsy and Autism

Ashura W. Buckley and Gregory L. Holmes

Immunity and Inflammation in Epilepsy Annamaria Vezzani, Bethan Lang and Eleonora Aronica

Hyperpolarization-Activated Cyclic

Nucleotide-Gated (HCN) Channels in Epilepsy Gary P. Brennan, Tallie Z. Baram and Nicholas P. Poolos

The Role of Calcium Channels in Epilepsy Sanjeev Rajakulendran and Michael G. Hanna

Interneuron Transplantation as a Treatment for Epilepsy

Robert F. Hunt and Scott C. Baraban

\section{Common Mechanisms Underlying Epileptogenesis and the Comorbidities of Epilepsy \\ Andrey Mazarati and Raman Sankar}

\section{The Diathesis-Epilepsy Model: How Past Events} Impact the Development of Epilepsy and Comorbidities

Christophe Bernard

Potassium Channels in Epilepsy

Rüdiger Köhling and Jakob Wolfart

GABAergic Synchronization in Epilepsy Roustem Khazipov

Status Epilepticus Syndi Seinfeld, Howard P. Goodkin and Shlomo Shinnar

Neonatal and Infantile Epilepsy: Acquired and

Genetic Models Aristea S. Galanopoulou and Solomon L. Moshé

Epigenetics and Epilepsy

David C. Henshall and Katja Kobow

Microcircuits in Epilepsy: Heterogeneity and Hub Cells in Network Synchronization

Anh Bui, Hannah K. Kim, Mattia Maroso, et al.

For additional articles in this collection, see http://perspectivesinmedicine.cshlp.org/cgi/collection/ 